\title{
Comparison of Polymorphonuclear Leukocyte Functions in Elderly Patients and Healthy Young Volunteers
}

\author{
Pervin Göçer ${ }^{a}$ Ümran S. Gürer ${ }^{a}$ Nilgün Erten ${ }^{b}$ Şükrü Palandüz \\ Erkan Rayaman $^{\mathrm{a}}$ Burçak Akarsu ${ }^{\mathrm{a}}$ Akif Karan ${ }^{\mathrm{b}}$ Adile Çevikbaş ${ }^{\mathrm{a}}$ \\ ${ }^{a}$ Department of Pharmaceutical Microbiology, Faculty of Pharmacy, University of Marmara, \\ ${ }^{b}$ Department of Internal Medicine, Istanbul Faculty of Medicine, University of Istanbul, Istanbul, Turkey
}

\section{Key Words}

Polymorphonuclear leukocyte · Phagocytosis ·

Intracellular killing activity · Hypertension •

Diabetes mellitus $\cdot$ Cancer

\begin{abstract}
Objective: To compare the polymorphonuclear leukocyte (PMN) functions (phagocytosis and intracellular killing activity) of elderly patients with healthy young volunteers. Subjects and Methods: Fifty-nine elderly patients who had various diseases (cancer, hypertension and diabetes mellitus, DM) and 10 healthy young volunteers were included in this study. Ficoll-Hypaque gradient centrifugation was used to isolate PMNs from venous blood containing EDTA $(0.1 \mathrm{~g} / \mathrm{ml})$. Phagocytosis and intracellular killing activity of neutrophils were assayed using a modification of Alexander's method, in which serum opsonins, number of neutrophils and number of microorganisms are standardized in order to detect both increases and decreases in phagocytosis and intracellular killing as well as combined abnormalities of these two functions. The least significant difference test was used to compare the results in the two groups. $\boldsymbol{R e}$ sults: Phagocytic activity of PMNs from patients with cancer was significantly higher than that of healthy
\end{abstract}

young volunteers $(p<0.05)$ and elderly patients with hypertension and DM $(p<0.05)$. There was no statistical difference between the phagocytic activity of PMNs from elderly patients with hypertension and DM and healthy young volunteers $(p>0.05)$. The intracellular killing activity of PMNs from elderly patients with hypertension, $D M$ and cancer was significantly lower than that of healthy young volunteers $(p=0.001, p<0.0001, p=$ 0.003 , respectively). Conclusions: The intracellular killing activity of PMNs from elderly patients was significantly decreased when compared with that of healthy young volunteers. Ageing, chronic diseases and drugs used in the treatment of these elderly patients may be the cause for decreased intracellular killing activity.

Copyright (C) 2005 S. Karger AG, Basel

\section{Introduction}

Ageing is a dynamic phenomenon, and many defects in all functions of the elderly, including changes in the immune functions during senescence, have been documented. Ageing is considered to be a common predisposing factor to the immunodeficiency syndrome. 'Immunosenescence' is the deterioration of the immune system in elderly people, and it is thought that these people suf-

\section{KARGER}

Fax +4161306 1234

E-Mail karger@karger.ch

www.karger.com
(C) 2005 S. Karger AG, Basel

$1011-7571 / 05 / 0146-0382 \$ 22.00 / 0$

Accessible online at:

www.karger.com/mpp
Adile Çevikbaş

Department of Pharmaceutical Microbiology, Faculty of Pharmacy

University of Marmara

TR-34628 Haydarpaşa, Istanbul (Turkey)

Tel. +90 21641429 62, Fax +90 21634529 52, E-Mail fmikrobiyoloji@hotmail.com 
fer higher rates of morbidity and mortality from infections, possibly autoimmune diseases and cancer [1-4].

Phagocytic cells, such as polymorphonuclear leukocytes (PMNs) perform an important defensive function against infectious agents such as bacteria, viruses and fungi. Many investigations have revealed that neutrophil phagocytic ability, intracellular killing capacity, superoxide production and enzyme release are impaired during senescence $[1,3,5,6]$. Some studies have demonstrated a decrease in the microbicidal activity of PMNs, as well as a decrease in oxidative metabolism when PMNs are stimulated with a phagocytic stimulus, and have related these to the ageing process $[7,8]$.

Hence we decided to assess PMN functions (phagocytic and intracellular killing activity) of elderly patients and compare them with healthy young volunteers.

\section{Subjects and Methods}

\section{Subjects}

Sixty-nine consecutively selected subjects were included in this study: 59 elderly patients with a mean age of 73.2 years (range 60-92) and 10 healthy young volunteers as controls (mean age 25 years, range 20-31). All of the volunteers were drug-free individuals. Of the elderly patients, 33 had hypertension, 17 diabetes mellitus (DM) and 9 cancer. Blood was taken from the 59 elderly patients who were hospitalized and were being treated with various drugs appropriate for their diseases [the hypertensive patients were treated with enalapril $(5 \mathrm{mg})$, verapamil $(40 \mathrm{mg})$ and patients with cancer who had stomach ache were treated with ranitidin $(3 \times$ $10 \mathrm{mg})$ ]. Additionally the hypertensive patients and patients with cancer were given vitamin supplementation [vitamin A $(300,000$ IU/daily, p.o.) and vitamin B (250 mg thiamine and $250 \mathrm{mg}$ pyridoxine daily, p.o.)] in the Department of Internal Medicine, Istanbul Faculty of Medicine, University of Istanbul, Turkey. Ethics committee approval was obtained prior to the study.

\section{Methods}

Phagocytic and intracellular killing activities of the PMNs were assayed using a modification of Alexander's method [9]. In the modified method, Ficoll was used in place of dextran and PMNs were counted by microscope instead of standard pour plate technique. The PMNs were isolated from the venous blood by the Ficoll-Hypaque gradient centrifugation method [10, 11]. Twenty milliliters of venous blood was drawn from both elderly patients and the control subjects into $0.1 \mathrm{~g} / \mathrm{ml}$ ethylenediaminetetraacetic acid. The blood was centrifuged at $1,048 \mathrm{~g}$ for $30 \mathrm{~min}$, the buffy-coat layer was removed, added to Ficoll-Hypaque plus Polymorphprep solution and centrifuged at 1,509 $\mathrm{g}$ for $30 \mathrm{~min}$. The PMN layer was removed, washed 3 times and suspended in Hank's Buffered Salt Solution (HBSS).

Viability of PMNs was assayed as 98\% (by trypan blue staining), and cell density was adjusted by dilution to $1 \times 10^{7}$ cells $/ \mathrm{ml}$ using methods described previously [10, 11].
Table 1. Phagocytic and intracellular killing activity of polymorphonuclear leukocytes from elderly patients with hypertension, DM and cancer and from healthy young volunteers

\begin{tabular}{lrll}
\hline Donors & $\mathrm{n}$ & $\begin{array}{l}\text { Phagocytic } \\
\text { activity, } \%\end{array}$ & $\begin{array}{l}\text { Intracellular } \\
\text { killing activity, \% }\end{array}$ \\
\hline Hypertensive elderly & 33 & $45.67 \pm 16.10$ & $4.82 \pm 4.49 * * *$ \\
Diabetic elderly & 17 & $46.76 \pm 23.99$ & $2.94 \pm 1.78^{* * * *}$ \\
Elderly with cancer & 9 & $62.89 \pm 18.94 *$ & $4.39 \pm 4.00^{* *}$ \\
Young volunteers & 10 & $45.00 \pm 7.49$ & $9.50 \pm 2.59$ \\
\hline \multicolumn{2}{c}{$* 0.05, * * \mathrm{p}=0.003, * * * \mathrm{p}=0.001, * * * *$} & $\mathrm{p}<0.0001$. \\
\hline
\end{tabular}

A clinical strain of Candida albicans was used to determine the phagocytic and intracellular killing activity of PMNs. C. albicans viability was assayed as greater than $98 \%$ by methylene blue staining. PMNs suspended in HBSS were incubated at $37^{\circ} \mathrm{C}$ for $30 \mathrm{~min}$ in a shaking incubator. C. albicans (in another tube) was suspended in HBSS, and then an aliquot of sterile human serum (1:4) was added (in order to opsonize it) followed by incubation at $37^{\circ} \mathrm{C}$ for $30 \mathrm{~min}$. Yeast cells were then added to the PMN tube, and the final mixture contained $5 \times 10^{6} \mathrm{PMNs} / \mathrm{ml}$ and $5 \times 10^{6}$ yeast cells $/ \mathrm{ml}$. Dead yeast cells were determined after adding $0.01 \%$ methylene blue stain (1:1 ratio) in the last $5 \mathrm{~min}$ of the incubation. The phagocytic activity was determined by the percentage of PMNs that had phagocytosed yeast cells. The intracellular activity was determined by the percentage of PMNs that included killed yeast cells as described previously $[10,11]$.

The phagocytic and intracellular killing activity of PMNs from elderly patients with hypertension, DM, cancer and healthy young volunteers were recorded and subjected to statistical analysis.

\section{Statistics}

The results were expressed as means \pm SD. Differences between groups were examined by using the least significant difference (LSD) test and $p$ values $\leq 0.05$ were considered statistically significant.

\section{Results}

The phagocytic and intracellular killing activities of the PMN leukocytes are recorded in table 1. Phagocytic activity greater than $30 \%$ and intracellular killing activity more than $4 \%$ were regarded as normal values. There was no significant difference between the phagocytic activity of PMNs from elderly patients with hypertension and $\mathrm{DM}$ and healthy young volunteers $(\mathrm{p}>0.05)$. However, the phagocytic activity of PMNs from elderly patients with cancer was significantly higher than that of healthy young volunteers $(\mathrm{p}<0.05)$. 
The intracellular killing activity of PMNs from elderly patients with hypertension, DM or cancer was significantly lower than that of healthy young volunteers ( $p=$ $0.001, p<0.0001, p=0.003$, respectively; table 1$)$. However, there was no significant difference between the intracellular killing activity of PMNs when the all groups (hypertension, DM and cancer) of elderly patients were compared between each other $(p>0.05)$. The phagocytic activity of PMNs from elderly patients with cancer was significantly higher than that of elderly patients with hypertension and DM $(\mathrm{p}<0.05)$.

\section{Discussion}

Our results show that with increasing age, the intracellular killing activity of PMNs, which have an important role in the cellular-mediated mechanism of immunity in elderly patients, decreased significantly when compared with that of healthy young volunteers, a result similar to previous reports $[2,7,12]$. Also the intracellular killing activity of PMNs from elderly patients with hypertension and DM decreased, but their phagocytic activity did not significantly decrease when compared with that of healthy young volunteers. However, the phagocytic activity of PMNs from patients with cancer was significantly higher than that of patients with hypertension, DM or healthy young volunteers $(p<0.05)$. In a study carried out on febrile neutropenic children with leukemia and treated with antibiotics, it has been shown that the phagocytic activity of PMNs was higher than the normal ranges [13]. This may be due to endogenous pyrogens, secreted by monocytes that surround the tumor mass during inflammation [14] and/or treatment with various antibiotics [13].

Ageing, chronic diseases and the drugs used in the treatment of elderly patients may be the cause for the decrease in PMN functions in this study group. Thus, it has been shown that enalapril $(5 \mathrm{mg} / \mathrm{kg})$ reduced the adherence of PMNs [15], verapamil $\left(10^{-4} \mathrm{~mol} / \mathrm{l}\right)$ inhibited leukocyte functions [16], and ranitidin $(30 \mathrm{mg} / \mathrm{kg}$, i.v.) inhibited the release of elastase as well as the production of $\mathrm{O}_{2}$ in PMNs [17]. The patients in this study had been placed on such treatments by the attending physicians.

While some investigations showed that only the phagocytic activity of PMNs decreased in elderly patients, others showed that only the PMN intracellular killing activity decreased with age, or that both phagocytic and intracellular killing activity decreased in the elderly group [1, $7,8]$. The findings with respect to intracellular killing by
PMNs in our study are similar to the findings in other studies. However, there was no significant difference between the phagocytic activity of PMNs from the elderly patients with hypertension and those with DM in our study. This might be a consequence of vitamin supplementation, which most of our elderly patients had taken during their treatment. It has been reported that vitamin $\mathrm{A}, \mathrm{B}$ and $\mathrm{E}$ supplementation significantly increased phagocytic activity of PMNs [18, 19].

\section{Conclusion}

Our results have demonstrated that the intracellular killing activity of PMNs in elderly patients is significantly decreased when compared with that of healthy young volunteers, indicating that ageing, chronic diseases and the drugs used in the treatment of these elderly patients may be the cause of the decrease in PMN functions.

\section{Acknowledgments}

The authors are thankful to the Marmara University Research Foundation and to the elderly patients and volunteers who provided blood samples for this study. 


\section{References}

$\checkmark 1$ Wenisch C, Patruta S, Daxböck F, Krause R, Hörl W: Effect of age on human neutrophil function. J Leukoc Biol 2000;67:40-45.

$>2$ Inoue M, Hashimoto S, Nakaya Y, Horie T: The role of G-CSF in the host defense mechanisms of the elderly. Nippon Ronen Igakkai Zasshi 1993;30:480-486.

3 Cordopatri F, Magaraci F, Iacona G, Scibilia G, Stivala F: Different behavior of phagocytes in young and old subjects. Boll Soc Ital Biol Sper 1992;68:337-342.

-4 Krause KH, Clark RA: Geneva biology of ageing workshop 2000: phagocytes, inflammation, and ageing. Exp Gerontol 2001;36:373-381.

$\checkmark 5$ Schröder AK, Rink L: Neutrophil immunity in elderly. Mech Ageing Dev 2003;124:419425.

-6 Butcher S, Chahel H, Lord JM: Ageing and the neutrophil: no appetite for killing? Immunology 2000;100:411-416.

-7 Wykretowicz A, Weirusz-Wysocka B, Wysocki J, Szczepanik A, Wysocki H: Impairment of the oxygen-dependent microbiocidal mechanism of polymorphonuclear neutrophils in patients with type- 2 diabetes is not associated with increased susceptibility to infection. Diabetes Res Clin Pract 1993;19:195-201.

$\checkmark 8$ Chan SS, Monteiro HP, Deucher GP, Abud RL, Abuchalla D, Junqueira BCV: Functional activity of blood polymorphonuclear leukocytes as an oxidative stress biomarker in human subjects. Free Radic Biol Med 1998;24: 1411-1418
-9 Alexander JW, Windhorst DB, Good RA: Improved tests for the evolution of neutrophil function in human disease. $\mathrm{J}$ Lab Clin Med 1968;72:136-148.

10 Soyogol Gürer Ü, Büyüköztürk S, Palandüz Ş, Rayaman E, Çolakoğlu B, Çevikbaş A: The effects of allergen-specific immunotherapy on polymorphonuclear leucocyte functions in patients with seasonal allergic rhinitis. Int Immunopharmacol 2005;5:661-666.

11 Barbior BM, Cohen HJ: Measurement of neutrophil function: Phagocytosis, degranulation, the respiratory burst and bacterial killing; in Cline MJ (ed): Methods in Hematology, Leukocyte Function. New York, Churchill Livingstone, 1981, pp 1-39.

12 Perskin MH, Cronstein BN: Age-related changes in neutrophil structure and function. Mech Ageing Dev 1992;64:303-313.

13 Rayaman E, Gürer SÜ, Yıldırmak Y, Palandüz A, Göçer P, Yıldırım A, Çevikbaş A, Kayaalp $\mathrm{N}$ : Antibiyotiklerin ve A vitamininin kemoterapi alan febril ve nonfebril nötropenik hastalarin polimorf nüveli lökosit fonksiyonlari üzerine in vitro etkisi (poster No 12-12) 30. Türk Mikrobiyoloji Kongresi, 30 Eylül-5 Ekim, Antalya, 2002.
14 Carpenter CCJ, Ellner JJ, Lederman M: Ateş ve ateşli hasta; in Andreoli TE, Carpenter CJ, Plum F, Smith LH (eds): Cecil Essentials of Medicine. Philadelphia, Saunders, 1986, p 754.

15 Guba M, Steinbauer M: Differential effects of short-time ace- and AT1-receptor inhibition on postischemic injury and leukocyte adherence in vivo and in vitro. Shock 2000;13:190196.

16 Blank I, Baudish W: Effect of verapamil and nifedipine on the adhesion, migration and phagocytosis of human neutrophilic granulocytes. Haematol Int Mag Klin Morphol Blutforsch 1987;114:117-125.

17 Okajima K, Murakami K, Liu W, Uchiba M: Inhibition of neutrophil activation by ranitidine contributes to prevent stress-induceed gastric mucosal injury in rats. Crit Care Med 2000;28:2858-2865.

18 Akarsu S, Gürer SÜ, Gürbüz B, Altunay H, Çevikbaş A, Johansson C: A vitamininin kızamık hastalarının polimorf nüveli lökosit fonksiyonları üzerine etkisinin ex vivo araştırılması. Türk Mikrobiyol Cem Derg 2003;33:205-210.

19 İmamoğlu Ç, Gürer SÜ, Çevikbaş A, Palandüz Ş, Daşdelen N, Johansson C: Non-antimikrobiklerin insan polimorf nüveli lökosit fonksiyonları üzerine in vitro ve ex vivo etkisinin araştırılması. Türk Mikrobiol Cem Derg 2001;31:113-118. 
Filename: mpp734

Article-No: 734, Fig.: 0, Tab.: 1

$<$ Issueid $>006<$ /Issueid $>$

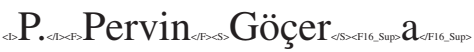

Ü.S. Ümran S. Gürer

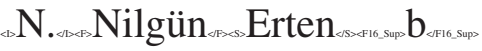

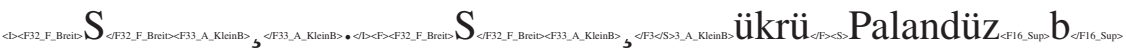

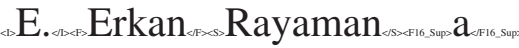

B. Burçak B $_{\ldots}$ Akarsu

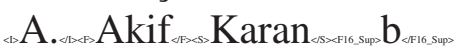

A. A. Adile Adileschevikba

Sorry, there is no abstract. Read the first few lines of the text instead! 